\section{DNA barcoding of threatened fishes of Bangladesh}

\section{Zarif Hossain', Nusrat Jahan Sanzida², Md. Anwarul Azim Akhand' and Md. Sagir Ahmed $^{2 *}$}

${ }^{1}$ Department of Oceanography, University of Dhaka, Dhaka1000, Bangladesh.

${ }^{2}$ Department of Zoology, University of Dhaka, Dhaka1000, Bangladesh.
Bioresearch Communications

Volume 7, Issue 2, July 2021

DOI:

https://doi.org/10.3329/brc.v7i2.54373

\begin{abstract}
The ichthyofaunal diversity of Bangladesh is declining dramatically due to various anthropogenic factors. For authentic identification at species level, approximately $655 \mathrm{bp}$ of the mitochondrial cytochrome c oxidase subunit I (COI) gene of 29 threatened fish species were amplified and a barcode dataset was generated. Among these species, $7 \%$ were categorized as Critically Endangered (CR), whereas $55 \%$ and $38 \%$ were categorized as Endangered (EN) and Vulnerable (VU), respectively. K2P genetic distances were evaluated and found to be increasing with higher taxonomic rank-1.01\% to $13.09 \%$ within species and $17.42 \%$ to $41.57 \%$ between species with a DNA barcode gap of $4.33 \%$. The average $\%$ GC content of the fish species was $44.7 \pm 0.49$. On the other hand, the \%GC values for the 6 orders-Cypriniformes, Siluriformes, Synbranchiformes, Syngnathiformes, Perciformes and Osteoglossiformes were $44.8 \pm 0.81,45.6 \pm 0.61,44.8 \pm 0.85,47 \pm 0.99,46.3 \pm 0.89,47 \pm 0.90$, respectively. The $\% \mathrm{GC}$ content was highest in the first codon followed by the second and third codons for both the individual species and the Orders $\left(1^{\text {st }}>2^{\text {nd }}>3^{\text {rd }}\right)$. It was also observed that the most synonymous mutations occur at the $3^{\text {rd }}$ codon position followed by the $1^{\text {st }}$ and the $2^{\text {nd }}$ codons. Finally, genetic variations were identified in Raiamas bola (at position 101), Ompok bimaculatus (at position 396) and Cirrhinus reba (at positions 108, 273, 310, $345,420,462,495,540$ and 591) including 3 incidents of transversion (A instead of C). Thus, two different groups of $C$. reba emerged in the phylogram. This study, for the first time, focuses on COI based molecular characterization of the threatened fish species of Bangladesh and therefore, might work as a referral study for their authentic identification and in-situ conservation.
\end{abstract}

KEYWORDS: COI, Barcoding, Threatened fish, Genetic diversity, Cirrhinus reba, Phylogeny.

RECEIVED: 18 March 2021, ACCEPTED: 08 June 2021

TYPE: Original Research
CORRESPONDING AUTHOR: Md. Sagir Ahmed, PhD, Department of Zoology, University of Dhaka, Dhaka-1000, Bangladesh,

Email: sagir@du.ac.bd

\section{Introduction}

Bangladesh is very rich in ichthyofaunal diversity since its geophysical condition. This diversity is declining day by day due to various reasons including habitat loss, indiscriminate fishing and aquatic pollution. It is a matter of huge concern that among 253 recorded freshwater fishes, 64 are assessed as different categories of threatened status, whereas globally only four of them has been categorized as threatened so far $^{1}$. The first step towards conserving and managing threatened fishes is the correct identification of the respective species. Due to genetic variability, phenotypic plasticity, morphologically cryptic taxa, different stages of life cycle and necessity of high level of taxonomic expertise-identification based on morphological characteristics seems to be deficient at times ${ }^{2-5}$. DNA barcoding can solve this conundrum by correctly referring an unknown specimen to an already known species as well as identifying a new species altogether by utilizing a short stretch of universal DNA sequence ${ }^{6-8}$.

So far, some universal DNA sequences have been reported to discriminate individuals belonging to different groups of organisms. In 2003, 655 bp region of mitochondrial cytochrome c oxidase I (MT-CO1, COI or COX1) gene was established as a global barcoding method for animals ${ }^{2,9,10}$. In animals and in some eukaryotes, its mutation rate is high enough to discriminate different species whereas its sequence is conserved in the individuals belonging to the same species ${ }^{11-13}$. Identification of different fish species by the sequencing of COI is very effective, unambiguous and thus popular ${ }^{8,11,14}$ 16

Constructing a COI barcode datasets of threatened species is important for the characterization and subsequent enforcement of laws and regulations by Convention on International Trade of Endangered Species (CITES). Threatened fishes play a varied importance in the economy as some are exploited commercially and have high market value; e.g., Ompok pabo, Tor putitora, Rita rita, Sperata aor, etc. Some of them are also used as ornamental fishes such as Botia lohachata, Olyra longicaudata, Notopterus notopterus. Monopterus cuchia have medicinal value among the local community and is exported to other countries ${ }^{17}$. More importantly, a great dependence of the locals upon fishing for their livelihoods from open water capture fisheries have made these fishes more and more vulnerable. As per laws are concerned-profiling of their COI gene will help to identify these species to be withdrawn from market circulation and prevent from retail substitutions of commercial species by threatened ones ${ }^{15,16,18,19}$.

DNA barcoding of most of the freshwater fishes have already been conducted where COI sequences of some of these threatened fish species were also included ${ }^{20,21}$. Here, our objective is to focus mainly on the threatened fish species of Bangladesh and underscore their molecular and phylogenetic 
characterization. Therefore, in this study, we examined 29 threatened fishes of Bangladesh and constructed a COI based reference library.

\section{Materials and Methods}

\section{Study area and sample collection}

The study was conducted at the north-eastern region of Bangladesh, namely the Tanguar and the Hakaluki Haors along with their adjacent flood plains. Samples were collected from July 2015 to June 2017. Immediately after collection, the fish specimens were kept in cool ice box and carried to the Advanced Fisheries and DNA Barcoding Laboratory, Department of Zoology, University of Dhaka for morphometric and molecular identification. Digital photographs of collected specimens were taken immediately and morphological identification of specimens was confirmed following the literatures ${ }^{1,22,23}$.

\section{Genomic DNA extraction}

About $20 \mathrm{mg}(5 \mathrm{~mm})$ of fish tissue from the dorsal fin base was minced and homogenized gently in 2 volumes (w/v) cold TNES buffer/Lysis buffer. After adjusting the total volume up to $500 \mu \mathrm{L}, 10 \mu \mathrm{L}$ of Proteinase $\mathrm{K}$ was added. Subsequently, the Phenol-Chloroform-Isoamyl alcohol protocol was followed to isolate good quality genomic DNA ${ }^{23}$.

\section{$P C R$ amplification and product purification}

A 655-bp segment from the $5^{\prime}$ region of the mitochondrial COI gene was amplified using the following primers: FishF1 (5'TCAACCAACCACAAAGACATTGGCAC3') and FishR1 (3'TAGACTTCTGGG TGGCCAAAGAATCA5') ${ }^{8}$. The 25 $\mu \mathrm{L}$ PCR reaction mixes comprised of $12.5 \mu \mathrm{L}$ Taq Polymerase, $8.5 \mu \mathrm{L}$ Nano Pure water, $1 \mu \mathrm{L}$ forward primer and $1 \mu \mathrm{L}$ reverse primer. PCR reactions were carried out in 96-well plates using the Applied Biosystems Veriti ${ }^{\text {TM }}$ Thermal Cycler. Thermocycling comprised an initial step of $5 \mathrm{~min}$ at $95^{\circ} \mathrm{C}$ and 41 cycles of $30 \mathrm{~s}$ at $95^{\circ} \mathrm{C}, 30 \mathrm{~s}$ at $54^{\circ} \mathrm{C}$, and $1 \mathrm{~min}$ at $72^{\circ} \mathrm{C}$, with a final extension at $72^{\circ} \mathrm{C}$ for $5 \mathrm{~min}$. Amplicons were visualized on $1 \%$ agarose gel electrophoresis. PCR products were purified using PureLink ${ }^{\mathrm{TM}}$ PCR purification kit. Sequencing was done from external sources by Sanger's dideoxy sequencing using ABI PRISM 3730xl Genetic Analyzer exploiting the BigDye ${ }^{\circledR}$ Terminator v3.1 cycle sequencing kit chemistry.

\section{Bioinformatics analysis}

Each mt-COI sequence was uploaded in the Translation Tool of the ExPASy portal to generate respective amino acid sequences. The utilities of CLC Workbench v7.7.1 and Mega $\mathrm{X}$ were used to determine the percentage of nucleotide composition. After aligning the sequences with MUSCLE, the inter- and intra-species distances were computed using Kimura two parameter (K2P) substitution model ${ }^{24}$. K2P model is particularly suitable as we considered both the transitionaltransversional substitutions and the COI sequences of different species were closely similar to each other ${ }^{25}$. Using these distances, the Neighbor-Joining (NJ) method with a bootstrap value of 1000 replicates was applied taking all the orders of the fishes to represent the divergence pattern ${ }^{26,27}$. The statistical analyses and respective images were generated either in Excel 2013 or RStudio-1.2.5001 packages.

\section{Results}

\section{Conservation status of threatened species}

A total of 29 species of threatened fishes under 13 families and six orders were identified based on their morphometric and molecular characterization. Among these 29 species, two $(7 \%)$ were categorized as CR, whereas rest $16(55 \%)$ and 11 $(38 \%)$ species were categorized as EN and VU respectively ${ }^{1}$ (Table 1). But globally, six of them were NT, one EN and one them were VU ${ }^{28}$. In our study, Siluriformes was the largest representative Order (42\%) whereas both Perciformes and Syngnathiformes were the smallest ones (3\%).

Table 1. Partial COI sequences generated from 29 threatened fish species along with their GB Accession nos.

\begin{tabular}{lllll}
\hline Order & Family & Species & Status & Accession No. \\
\hline Cypriniformes & Cyprinidae & Barilius barna & EN & KY124376 \\
& & Chela cachius & VU & KT353102 \\
& & Cirrhinus reba & VU & KX455893 MG969514 \\
& & & MN083095 \\
& & Crossocheilus latius & EN & MG969525 MG969531 \\
& Oreichthys cosuatis & EN & KX455909 MN013419 \\
& Raiamas bola & EN & KY124369 \\
& Securicola gora & VU & MG969533 \\
& Cobitidae & Tor putitora & EN & KT762361 KT762379 \\
& & Botia dario & EN & MH087038 MH087045 \\
& & & MN171346 MN171347 \\
& & Botia lohachata & EN & KX424374 \\
& & & MN083135 MH087044 \\
\hline Osteoglossiformes & Lepidocephalichthys & VU & KY124364 MF140396 \\
& Notopteridae & Chitala chitala & EN & MF140393 \\
\hline
\end{tabular}




\begin{tabular}{|c|c|c|c|c|}
\hline & & Notopterus notopterus & VU & KT346361 KT364757 \\
\hline Perciformes & Channidae & Channa marulius & $\mathrm{EN}$ & KX808573 MG969516 \\
\hline \multirow[t]{12}{*}{ Siluriformes } & Bagridae & Hemibagrus menoda & VU & KT762363 MG969522 \\
\hline & & Rita rita & $\mathrm{EN}$ & KT364781 KT762374 \\
\hline & & Sperata seenghala & VU & $\begin{array}{l}\text { KT364786 KT762382 } \\
\text { MN171374 }\end{array}$ \\
\hline & & Sperata aor & VU & KT762381 \\
\hline & Chacidae & Chaca chaca & EN & KX455900 MN083143 \\
\hline & Olyridae & Olyra longicaudata & EN & MF176156 KT762373 \\
\hline & Schilbeidae & Clupisoma garua & EN & KX455904 \\
\hline & Siluridae & Ompok bimaculatus & EN & $\begin{array}{l}\text { KT762368 MH087040 } \\
\text { MN083156 }\end{array}$ \\
\hline & & Ompok pabda & EN & $\begin{array}{l}\text { KT364760 KT762383 } \\
\text { MN200457 }\end{array}$ \\
\hline & & Ompok pabo & CR & KX455911 \\
\hline & & Wallago attu & VU & KX657717 МH087042 \\
\hline & Sisoridae & Bagarius bagarius & $\mathrm{CR}$ & $\begin{array}{l}\text { KT762371 KX455910 } \\
\text { MG969530 MN200478 }\end{array}$ \\
\hline \multirow[t]{2}{*}{ Synbranchiforms } & Mastacembelidae & Mastacembelus armatus & EN & KT762364 \\
\hline & Synbranchidae & Monopterus cuchia & VU & MG969535 \\
\hline Syngnathiformes & Syngnathidae & Microphis deocata & VU & KT762375 \\
\hline
\end{tabular}

\section{Genetic divergence and \%GC content}

Intraspecies and interspecies K2P distances were calculated. Genetic divergence was observed to be increased as expected, with higher taxonomic rank-1.01\% to $13.09 \%$ within species, whereas $17.42 \%$ to $41.57 \%$ between species with a DNA Barcoding Gap of $4.33 \%$ (Figure 1). The mean intraspecies and interspecies K2P distances were $4.07 \pm 0.79$ and $30.74 \pm 0.19$, respectively (Table 2).

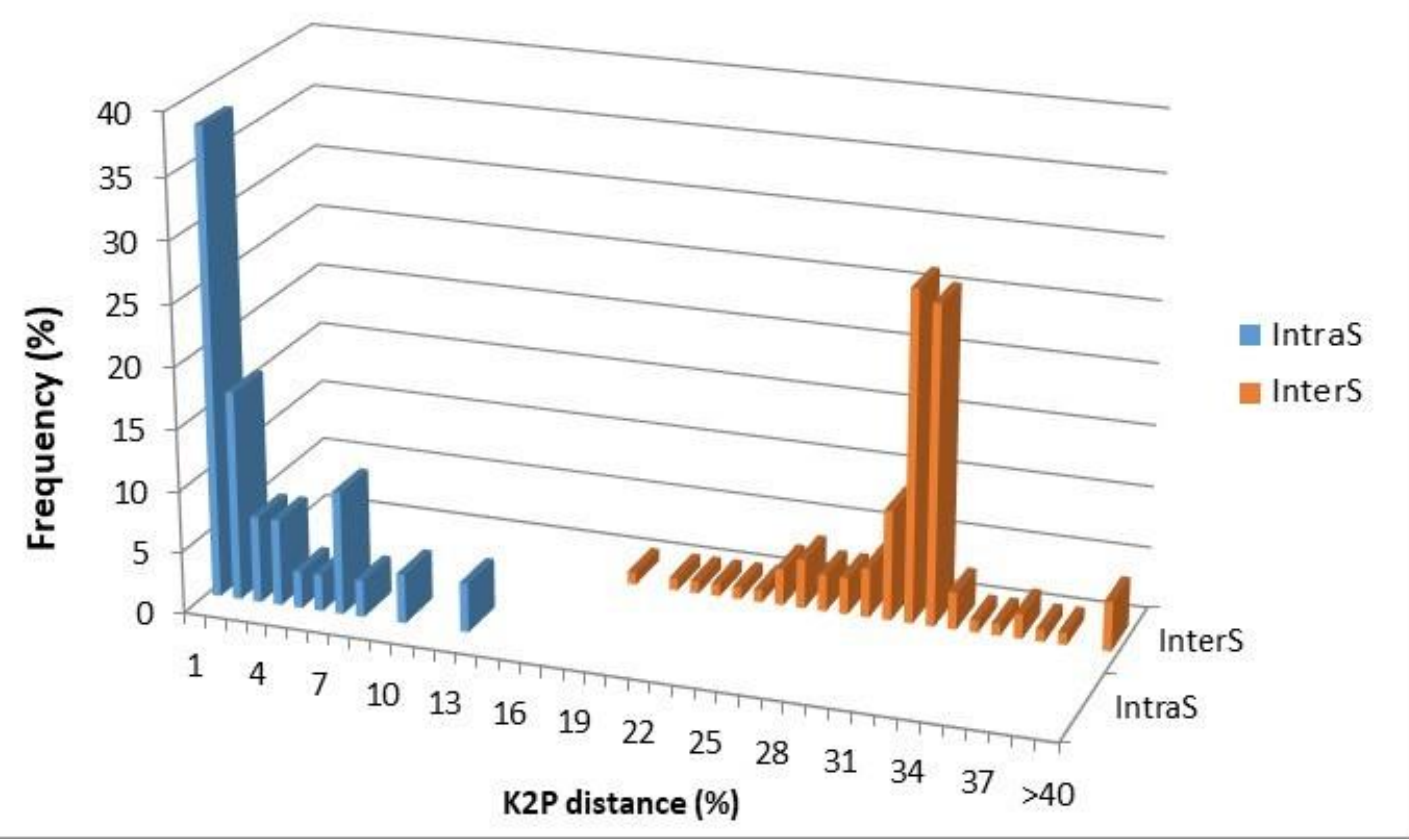

Figure 1. Genetic Divergence within Intraspecies (IntraS) and Interspecies (InterS). The genetic distance was computed using Kimura-2-Parameter (K2P) substitution model. 
Table 2. Minimum, maximum, mean and median K2P (\%) within and between species

\begin{tabular}{ccccc}
\hline & Min. & Max. & Mean & Median \\
\hline Intraspecies & 1.01 & 13.09 & $4.07 \pm 0.79$ & 2.30 \\
Interspecies & 17.42 & 41.57 & $30.74 \pm 0.19$ & 31.17 \\
\hline
\end{tabular}

In case of the median values, they were 2.30 and 31.17 , respectively, which along with the mean values sharply distinguished taxonomic hierarchy. Most importantly, the lesser values of intraspecies than the interspecies K2P distance indicated that DNA barcoding was a powerful tool to identify and differentiate the threatened fish species of Bangladesh.

The pattern of \%GC content at different codons was $1^{\text {st }}>2^{\text {nd }}>3^{\text {rd }}$ for each species and pattern of synonymous mutation rate was $3^{\text {rd }}>1^{\text {st }}>2^{\text {nd }}$ (Table 3 ).

Table 3. GC content variation at $1^{\text {st }}, 2^{\text {nd }}$ and $3^{\text {rd }}$ codon

\begin{tabular}{|c|c|c|c|c|c|}
\hline SL No. & Name of the Species & Overall & $1^{\text {st }}$ Codon & $2^{\text {nd }}$ Codon & $3^{\text {rd }}$ Codon \\
\hline 1 & Ompok pabo & 48.7 & 57.3 & 41.8 & 47.0 \\
\hline 2 & Bagarius bagarius & 45.8 & 57.2 & 42.5 & 37.7 \\
\hline 3 & Barilius barna & 47.6 & 55.4 & 43.2 & 44.1 \\
\hline 4 & Oreichthys cosuatis & 42.0 & 55.6 & 41.8 & 28.4 \\
\hline 5 & Raiamas bola & 47.8 & 58.6 & 43.3 & 41.4 \\
\hline 6 & Tor putitora & 44.5 & 57.6 & 43.0 & 32.9 \\
\hline 7 & Botia dario & 42.7 & 54.3 & 43.4 & 30.3 \\
\hline 8 & Botia lohachata & 42.8 & 54.7 & 42.2 & 31.5 \\
\hline 9 & Chitala chitala & 43.8 & 55.7 & 42.4 & 33.5 \\
\hline 10 & Channa marulius & 49.1 & 57.3 & 43.7 & 46.5 \\
\hline 11 & Rita rita & 43.0 & 55.0 & 43.6 & 30.4 \\
\hline 12 & Ompok bimaculatus & 45.4 & 58.1 & 43.0 & 35.1 \\
\hline 13 & Ompok pabda & 48.7 & 57.5 & 42.7 & 46.0 \\
\hline 14 & Clupisoma garua & 43.7 & 56.0 & 42.2 & 32.8 \\
\hline 15 & Chaca chaca & 48.3 & 57.8 & 42.2 & 44.8 \\
\hline 16 & Olyra longicaudata & 44.8 & 56.3 & 42.5 & 35.5 \\
\hline 17 & Mastacembelus armatus & 45.4 & 55.9 & 42.5 & 37.7 \\
\hline 18 & Chela cachius & 40.8 & 53.9 & 44.3 & 24.1 \\
\hline 19 & $\begin{array}{l}\text { Lepidocephalichthys } \\
\text { annandalei }\end{array}$ & 46.1 & 54.6 & 43.3 & 40.4 \\
\hline 20 & Notopterus notopterus & 43.7 & 55.1 & 43.1 & 32.9 \\
\hline 21 & Sperata aor & 43.5 & 55.5 & 42.5 & 32.5 \\
\hline 22 & Sperata seenghala & 44.2 & 54.9 & 42.7 & 35.0 \\
\hline 23 & Wallago attu & 45.3 & 56.9 & 43.4 & 35.5 \\
\hline 24 & Microphis deocata & 45.7 & 55.5 & 43.4 & 38.2 \\
\hline 25 & Cirrhinus reba & 43.7 & 56.4 & 43.1 & 31.5 \\
\hline 26 & Hemibagrus menoda & 42.4 & 56.4 & 42.7 & 28.3 \\
\hline 27 & Securicula gora & 48.7 & 57.8 & 43.1 & 45.2 \\
\hline 28 & Crossocheilus latius & 42.7 & 56.0 & 43.1 & 29.2 \\
\hline \multirow[t]{2}{*}{29} & Monopterus cuchia & 38.3 & 55.0 & 42.7 & 17.4 \\
\hline & Avg. \pm SD & $44.7 \pm 0.49$ & $56.1 \pm 0.23$ & $42.8 \pm 0.11$ & $35.1 \pm 1.32$ \\
\hline
\end{tabular}

The \% GC content in case of vertebrate mitochondrial COI gene tends to be greater $(\approx 45 \%)$ whereas in case of invertebrate mitochondrial COI sequence, high amount of AT is usually observed ${ }^{2}$. In our study, the GC content matched that of the sequence of vertebrate COI $(44.7 \pm 0.49)$. The pattern of standard error of mean (SEM) or synonymous mutation rate at different codon positions was also observed and it was $3^{\text {rd }}>1^{\text {st }}>2^{\text {nd }}$ (SEM for $3^{\text {rd }}, 1^{\text {st }}$ and $2^{\text {nd }}$ codon positions were $1.32,0.23$ and 0.11 , respectively).

The pattern of $\% \mathrm{GC}$ content at different codons was $1^{\text {st }}>2^{\text {nd }}>3^{\text {rd }}$ for each order and pattern of synonymous mutation rate was $3^{\text {rd }}>1^{\text {st }}>2^{\text {nd }}$ (Table 4 ). 
Table 4. GC content variation in threatened fishes of different Orders

\begin{tabular}{lclcccc}
\hline Order & Min. & Mean & Max. & 1st Codon & 2nd Codon & 3rd Codon \\
& & & & & & \\
\hline Cypriniformes & 40.8 & $44.8 \pm 0.81$ & 48.7 & $56.1 \pm 0.45$ & $43.1 \pm 0.17$ & $35.2 \pm 1.19$ \\
\hline Osteoglossiformes & 40.1 & $47 \pm 0.90$ & 51.2 & $56.7 \pm 0.51$ & $42.5 \pm 0.12$ & $42 \pm 2.26$ \\
\hline Perciformes & 41.2 & $46.3 \pm 0.89$ & 50.2 & $55.1 \pm 0.5$ & $43.1 \pm 0.19$ & $40.9 \pm 2.70$ \\
\hline Siluriformes & 42.4 & $45.6 \pm 0.61$ & 48.9 & $56.7 \pm 0.28$ & $42.5 \pm 0.13$ & $37.5 \pm 1.7$ \\
\hline Synbranchiformes & 38.3 & $44.8 \pm 0.85$ & 48.1 & $54.7 \pm 0.52$ & $42.9 \pm 0.15$ & $36.8 \pm 0.24$ \\
\hline Syngnathiformes & 40.3 & $47 \pm 0.99$ & 53.6 & $55.8 \pm 0.6$ & $43.1 \pm 0.12$ & $41.8 \pm 2.51$ \\
\hline
\end{tabular}

GC content variation in the 6 Orders constituted by the fish species was quite intriguing. The minimum overall value of GC content was the lowest for Osteoglossiformes (40.1\%), whereas that of Syngnathiformes was the highest (53.6\%). Such values indicated that the most synonymous mutations occur at the $3^{\text {rd }}$ position, with a few at the $1^{\text {st }}$ position and the least at the $2^{\text {nd }}$. Similarly, this was also observed in Australian fish and the Crustaceans ${ }^{8,29}$. This pattern between vertebrate and invertebrate might raise the interest of further studies to clarify whether this characteristic is conserved in all the organisms having COI. The six Orders were arranged in an ascending Order of the median value of \%GC content as shown in Fig-2.

\section{Distribution of Ascending GC \%}

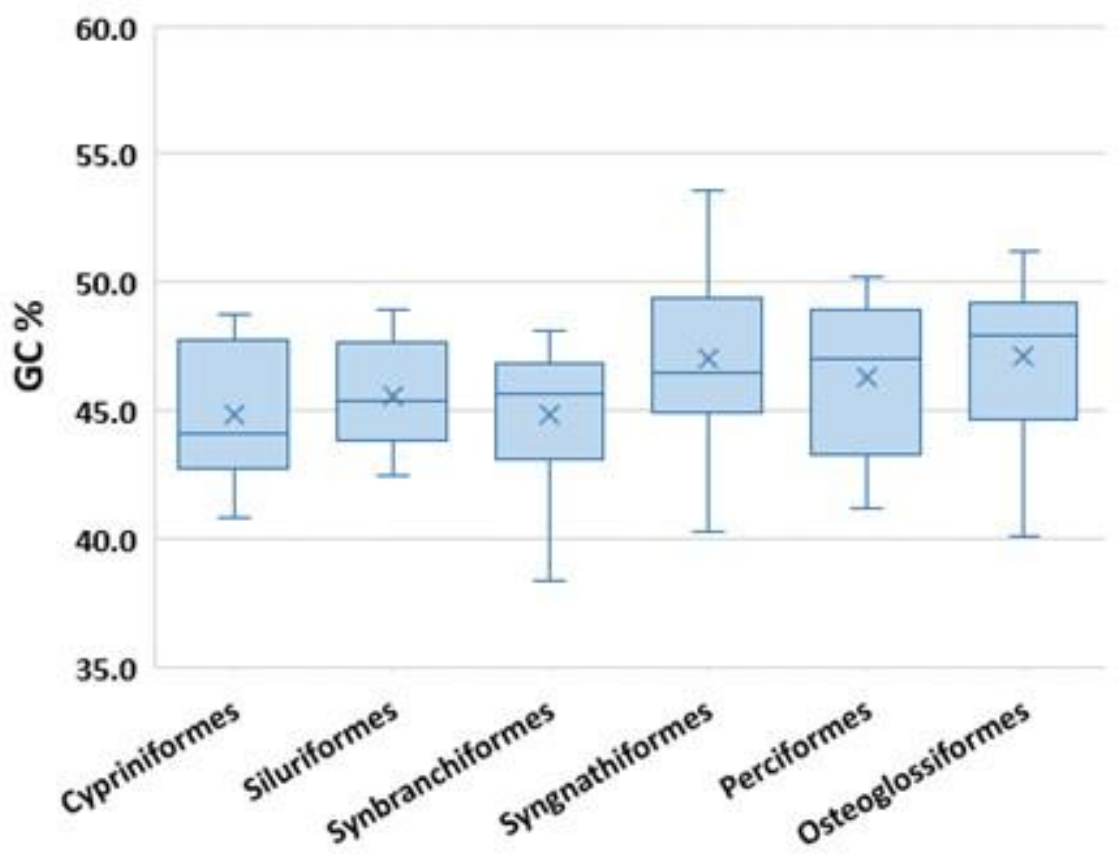

Figure 2. Boxplot distribution of ascending \%GC content of different orders of threatened fishes. The mean values of \%GC content was identified with ' $x$ ' mark and they were somewhat near around the median values. 
Different ranges of GC\% were also observed across the 6 Orders constituting the fishes of Threatened categories. A wide range of $13.3 \%$ was observed in the Order Syngnathiformes.
Phylogenetic analyses

Phylogenetic analyses of the 29 species were conducted. The COI sequences associated with same species were consistently clustered together. The clade formation in the phylogram was coherent with the morphological characteristics of the species (Fig.3).

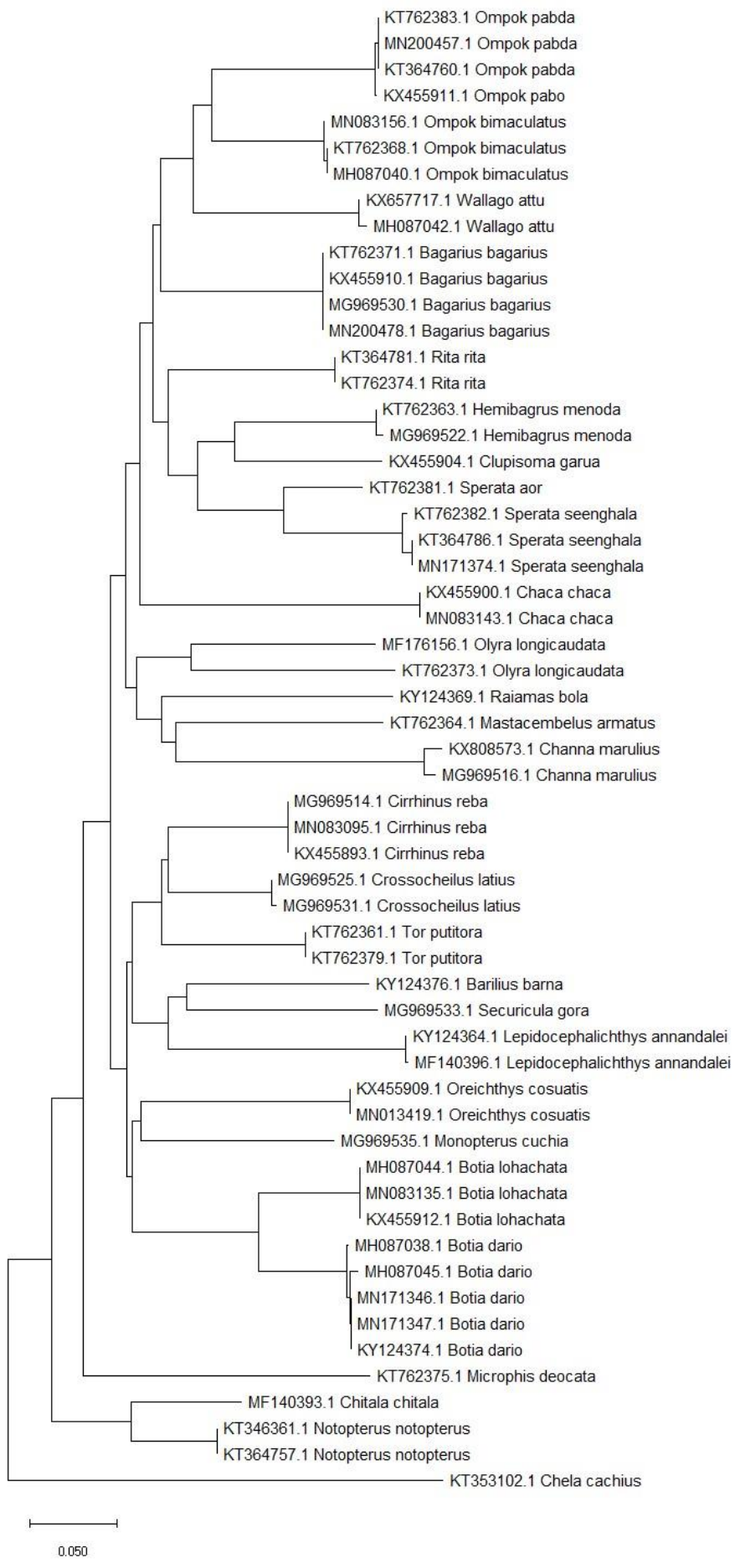

Figure 3. Phylogram of the Threatened Species. The Kimura-2-Parameter (K2P) distances among 57 COI sequences of 29 fish species were utilized to infer a Neighbor Joining tree. The rate variation was corrected with gamma distribution among sites. Nucleotide positions with missing data and gaps were completely deleted to attain the optimal data subset.

\section{Variation of nucleotides were found in three fish species}


Nucleotide variations in the individual fish representative of a particular species used in this study were analyzed. Among 11 cases of variation, three of them were transversions (3 cases of $\mathrm{C} / \mathrm{A}$ ), whereas the rest of the cases were just transitions. It was observed that purine to purine or pyrimidine to pyrimidine changes occur with greater frequency than purine to pyrimidine and vice versa. For $R$. bola and $O$. bimaculatus nucleotide variations were observed in the positions 101 and 396 , respectively as shown in Table 5.

Table 5. Nucleotide variations in the fish sequences

\begin{tabular}{lllll}
\hline SL No. & $\begin{array}{l}\text { Name of the } \\
\text { Species }\end{array}$ & $\begin{array}{l}\text { Position from the } \mathbf{5}^{\prime} \text { of } \\
\text { Forward Strand }\end{array}$ & $\begin{array}{l}\text { Common } \\
\text { Nucleotide }\end{array}$ & Variation \\
\hline $\mathbf{1}$ & $\begin{array}{l}\text { Raiamas bola } \\
\text { Ompok bimaculatus }\end{array}$ & 396 & $\mathrm{C}$ & $\mathrm{A}$ \\
\hline $\mathbf{3}$ & Cirrhinus reba & 108 & $\mathrm{G}$ & $\mathrm{A}$ \\
& 273 & $\mathrm{C}$ & $\mathrm{T}$ \\
& 310 & $\mathrm{~T}$ & $\mathrm{C}$ \\
& 345 & $\mathrm{C}$ & $\mathrm{T}$ \\
& 420 & $\mathrm{G}$ & $\mathrm{A}$ \\
& 462 & $\mathrm{C}$ & $\mathrm{A}$ \\
& 495 & $\mathrm{C}$ & $\mathrm{T}$ \\
& 540 & $\mathrm{C}$ & $\mathrm{A}$ \\
& 591 & $\mathrm{G}$ & $\mathrm{A}$ \\
\hline
\end{tabular}

Interestingly, it was observed that, the two sequences of $C$. reba from two different batches used in our study varied from the other $C$. reba individuals at 9 different sites (108, 273, 310, 345, 420, 462, 495, 540 and 591).

Moreover, to define the character of the variations in C. reba, six other COI sequences of this genus as well as ten other COI sequences of other species of Cirrhinus genera were used as test taxa. Furthermore, a phylogram was constructed that efficiently grouped different Cirrhinus species separately in different clades. More importantly, two different clusters of $C$. reba emerged, where our two specimens (labelled DUZM) were grouped together with two other sequences (Fig. 4). Interestingly, these two groups, when aligned, showed nucleotide variations at exactly nine places. Whether there are two varieties of $C$. reba species could be subjected to further studies.

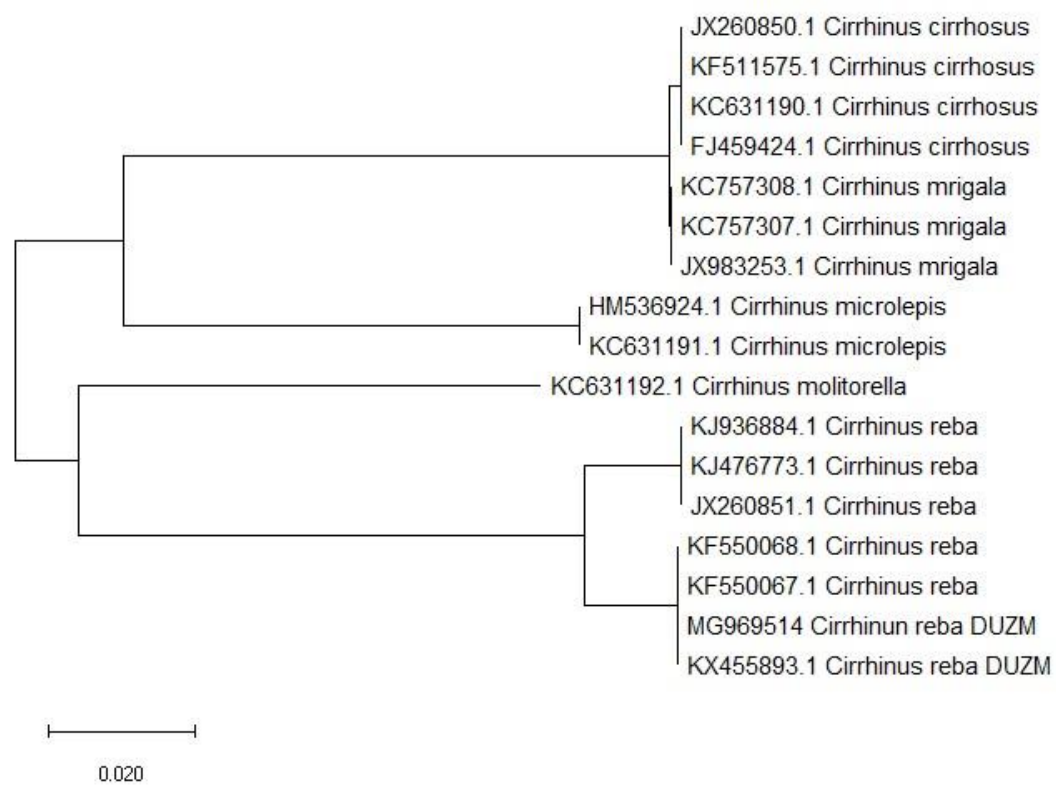

Figure 4. Phylogram of Cirrhinus genera. The Kimura-2-Parameter (K2P) distances among the COI sequences of different Cirrhinus species were utilized to infer a Neighbor Joining tree. The rate variation was corrected with gamma distribution among sites. Nucleotide positions with missing data and gaps were completely deleted to attain the optimal data subset. The COI sequences from our laboratory is labelled as 'DUZM.' 


\section{Discussion}

DNA based taxonomic system has emerged as a complementary and easy alternative to morphological identification system. In our study, we tried to demonstrate barcoding, an approach of sequencing a 655 bp region of the mitochondrial COI gene, as an effective and powerful tool to identify and characterize threatened fish species of Bangladesh.

In the present study, as expected, genetic divergence increased with higher taxonomic rank $-1.01 \%$ to $13.09 \%$ within species, whereas $17.42 \%$ to $41.57 \%$ between species (Fig. 1). A DNA barcoding gap of $4.33 \%$ was calculated which meant, in our barcode dataset, if two species were to be meant different, their COI sequences must have to be $4.33 \%$ different at least. It also indicated that no overlapping was present in the $\mathrm{K} 2 \mathrm{P}(\%)$ distances of intra and interspecies. This was also observed in the study of Australian fishes and decapods ${ }^{8,29}$. The K2P distance of intraspecies being sharply less than the interspecies supported the other studies. Specifically, for this study, the viability of DNA barcoding to characterize different fish species belonging to the three threatened categories was justified.

A wide range of \%GC was observed in the Orders with Syngnathiformes being the widest (Table 4). The wide range of \% GC content in some Orders such as this in our analysis was quite intriguing. But appraising a wider taxonomic breadth, large gaps in GC content (up to $8 \%$ ) were also detected even at the level of genera ${ }^{29}$. At different codons, both for the species and the Order, the \% content was $\mathrm{GC}_{1}>\mathrm{GC}_{2}>\mathrm{GC}_{3}$. Synonymous mutation rate was greatest at the $3^{\text {rd }}$ codon, with a few at the $1^{\text {st }}$ and the least at the $2^{\text {nd }}$ $\left({ }^{3 \mathrm{rd}}>1^{\text {st }} 2^{\text {nd }}\right)$. These patterns of $\% \mathrm{GC}$ content and synonymous mutation rates were also observed in other studies 2930318 .

Phylogenetic trees were constructed with the COI sequences in the studies of Canadian freshwater fishes, Asian seabass, Australian fish species, shark and ray fins and other fish species to observe whether they supported conventional taxonomy ${ }^{8,11,30,32,33}$. In our study, sequences of similar species were clustered together whereas sequences belonging to different fish species were separated. This supports the notion that DNA Barcoding is a reliable system of taxonomical identification for the threatened fish species of Bangladesh.

Two different groups of $C$. reba fishes emerged in the phylogram (Fig. 4). This also happened in the case studies of Lates calcarifer where distinct morphological differences between its two groups also happened along with the differences of COI ${ }^{33}$. Whether there are such morphological differences in between these two groups of $C$. reba must be subjected to extensive morphological classification and further genomic comparisons.

\section{Conclusion}

DNA barcoding as a microgenomic mapping system to differentiate organisms is frugal both in terms of money and labor. The study of COI sequences reveals salient features of an organism by simply improving the genomic resolution which could otherwise be easily neglected in whole genome sequencing or even morphological identification. We believe this claim to be substantiated especially by our nucleotide variation profile between two groups of $C$. reba. It is not our wish to claim DNA barcoding to be exhaustive, rather we propose that COI sequencing is not only a mere subsidiary to morphological identification but also the former can overcome several drawbacks of the latter. A COI database system could serve as a platform to the classification and identification of threatened fish species of Bangladesh as a part of biodiversity conservation as well as management. On the other hand, it can instigate a series of discovery and exploration of such microgenomic mapping systems to elucidate the gray areas of taxonomy and comparative genomics in the finest detail.

\section{Data availability statement}

The sequence data have been submitted to the NCBI GenBank database https://www.ncbi.nlm.nih.gov/genbank and have open public access.

\section{Conflicts of Interest}

The authors declare no conflict of interest.

\section{References}

1. IUCN Bangladesh, 2015. Red List of Bangladesh Volume 5: Freshwater Fishes. IUCN, International Union for Conservation of Nature, Bangladesh Country Office, Dhaka, Bangladesh.

2. Hebert PDN, Cywinska A, Ball SL, and deWaard JR, 2003. Biological identifications through DNA barcodes. Proceedings of the Royal Society of London Series B: Biological Sciences, 270(1512), pp. 313-21.

3. Bickford D, Lohman DJ, Sodhi NS, Ng PKL, Meier R, Winker K, et al., 2007. Cryptic species as a window on diversity and conservation. Trends in Ecology and Evolution, 22(3) pp. 148-55.

4. Knowlton N, 1993. Sibling Species in the Sea. Annual Review of Ecology and Systematics, 24(1), pp. 189-216.

5. Jarman SN, and Elliott NG, 2000. DNA evidence for morphological and cryptic Cenozoic speciations in the Anaspididae, 'living fossils' from the Triassic. Journal of Evolutionary Biology, 13(4), pp. 624-33.

6. Chen S, Yao H, Han J, Liu C, Song J, Shi L, et al., 2010. Validation of the ITS2 region as a novel DNA barcode for identifying medicinal plant species. PLOS ONE, 5(1).

7. Hollingsworth PM, Forrest LL, Spouge JL, Hajibabaei M, Ratnasingham S, van der Bank M, et al., 2009. A DNA barcode for land plants. Proceedings of the National Academy of Sciences of the United States of America, 106(31), pp. 12794-7.

8. Ward RD, Zemlak TS, Innes BH, Last PR, and Hebert PDN, 2005. DNA barcoding Australia's fish species. Philosophical Transactions of the Royal Society B: Biological Sciences, 360(1462), pp. 1847-57.

9. Miller SE, 2007. DNA barcoding and the renaissance of taxonomy. Proceedings of the National Academy of Sciences, 104(12), pp. 4775-6.

10. Tautz D, Arctander P, Minelli A, Thomas RH, and Vogler AP, 2003. A plea for DNA taxonomy. Trends in Ecology and Evolution, 18(2), pp. 70-74.

11. Hubert N, Hanner R, Holm E, Mandrak NE, Taylor E, Burridge M, et al., 2008. Identifying Canadian freshwater fishes through DNA barcodes. PLoS ONE, 3(6).

12. Frézal L, and Leblois R, 2008. Four years of DNA barcoding: current advances and prospects. Infection, Genetics and Evolution, 8(5), pp. 727-36. 
13. Ivanova N V., Zemlak TS, Hanner RH, and Hebert PDN, 2007. Universal primer cocktails for fish DNA barcoding. Molecular Ecology Notes, 7(4), pp. 544-8.

14. Radulovici AE, Archambault P, and Dufresne F, 2010. DNA Barcodes for Marine Biodiversity: Moving Fast Forward? Diversity, 2, pp. 450-72.

15. Smith PJ, McVeagh SM, and Steinke D, 2008. DNA barcoding for the identification of smoked fish products. Journal of Fish Biology, 72(2), pp. 464-71.

16. Ward RD, Hanner R, and Hebert PDN, 2009. The campaign to DNA barcode all fishes, FISH-BOL. Journal of Fish Biology, 74(2), pp. 329-56.

17. Siddiqui K, Islam M, Ahmed Z, and Kabir S, 2007. Encyclopedia of flora and fauna of Bangladesh. Asiatic Society of Bangladesh,.

18. Barbuto M, Galimberti A, Ferri E, Labra M, Barbuto M, Galimberti A, et al., 2018. DNA barcoding reveals fraudulent substitutions in shark seafood products: The Italian case of "palombo" (Mustelus spp.) Elsevier, 43(1), pp. 376-381.

19. H-K Wong E, and Hanner RH, 2008. DNA barcoding detects market substitution in North American seafood. Food Research International, 41(8), pp. 828-37.

20. Ahmed MS, Chowdhury MMK, and Nahar L, 2019. Molecular characterization of small indigenous fish species (SIS) of Bangladesh through DNA barcodes. Gene, 684, pp. 53-7.

21. Ahmed MS, Datta SK, and Zhilik AA, 2020. Molecular diversity of freshwater fishes of Bangladesh assessed by DNA barcoding. Bangladesh Journal of Zoology, 48(1), pp. 1-19. 22. Talwar P, 1991. Inland Fishes of India and Adjacent Countries. CRC Press.

23. Mamun Chowdhury M, Rahman M, Al Reza H, Sagir Ahmed M, Sharifur Rahman A, Nahar L, et al., 2016. Efficiency of Different DNA Extraction Methods for Fish
Tissues: A Comparative Analysis. Article in IOSR Journal of Pharmacy and Biological Sciences, 11(3), pp. 11-5.

24. Kimura M, 1980. Journal of Molecular Evolution A Simple Method for Estimating Evolutionary Rates of Base Substitutions Through Comparative Studies of Nucleotide Sequences. Journal of Molecular Evolution, 16, pp. 111-120.

25. Masatoshi Nei, and Sudhir Kumar, 2000. Molecular evolution and phylogenetics. Oxford University Press.

26. Saitou N, 1987. The neighbor-joining method: a new method for reconstructing phylogenetic trees. Molecular Biology and Evolution, 4(4), pp. 406-25.

27. Felsenstein J, 1985. Confidence Limits On Phylogenies: An Approach Using The Bootstrap. Evolution, 39(4), pp. 783 91.

28. IUCN, 2020. IUCN Red List of Threatened Species. Version 2020-2.

29. da Silva JM, Creer S, dos Santos A, Costa AC, Cunha MR, Costa FO, et al., 2011. Systematic and evolutionary insights derived from mtDNA COI Barcode diversity in the Decapoda (crustacea: Malacostraca). PLoS ONE, 6(5).

30. Holmes BH, Steinke D, and Ward RD, 2009. Identification of shark and ray fins using DNA barcoding. Fisheries Research, 95, pp. 280-8.

31. Jalali SK, 2015. DNA Barcoding for Identification of Agriculturally Important Insects Insect symbionts View project Indo-UK Collaborative Project on Antimicrobial Resistance in NE-INDIA View project. Springer, , pp. 13-23.

32. Vij S, Purushothaman K, Gopikrishna G, Lau D, Saju JM, Shamsudheen K V., et al., 2014. Barcoding of Asian seabass across its geographic range provides evidence for its bifurcation into two distinct species. Frontiers in Marine Science, 1(AUG).

33. Ward RD, Holmes BH, and Yearsley GK, 2008. DNA barcoding reveals a likely second species of Asian sea bass (barramundi) (Lates calcarifer). Journal of Fish Biology, 72(2), pp. 458-63. 